\title{
REVISTAMARACANAN
}

Artigo

\section{O regionalismo e suas implicações literárias na contística de Bernardo Élis}

The regionalism and its literary implications in te tales of Bernardo Élis

Fabianna Simão Bellizzi Carneiro*

Universidade Federal de Goiás

Goiânia, Goiás, Brasil

Recebido em: 29 jul. 2020.

Aprovado em: 10 jul. 2021.

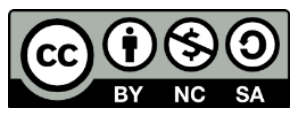

\footnotetext{
* Professora da Unidade Acadêmica de Letras e Linguística da Universidade Federal de Goiás - Universidade Federal de Catalão (em transição). Doutora em Literatura Comparada pela Universidade do Estado do Rio de Janeiro. Mestre em Estudos da Linguagem pela Universidade Federal de Goiás. Graduada em Comunicação Social e em Letras pela Universidade Federal de Goiás. (fabianna_bellizzi@yahoo.com.br)

(D) https://orcid.org/0000-0002-8600-2765 (6) http://lattes.cnpq.br/216992366593028
} 


\title{
Resumo
}

Este trabalho objetiva reforçar a importância do encontro entre história e literatura de forma a comprovar que tal movimento é benéfico à academia e necessário a futuros docentes. Para tanto, pautamos nossas discussões a partir da leitura do conto "A virgem santíssima do quarto de Joana", de Bernardo Élis (1915-1997). Essa narrativa, com toda sua potencialidade plástica e questões de cunho filosófico e existencialista, nos mostra que o regionalismo vai além do idílico ou exótico, e que sua migração para a literatura nos proporciona conhecer um Brasil incrustado nos ermos do sertão e ainda pouco lido nos compêndios escolares. Autores como Ligia Chiappini (2020), Marisa Lajolo (2007), Hayden White (1994), Lloyd S Kramer (1992) e outros devidamente referenciados compõem o arsenal teórico.

Palavras-chave: Regionalismo. Narrativa histórica. Narrativa literária. Bernardo Élis.

\begin{abstract}
This work aims to increase the significance of the encounter between history and literature in order to prove that such movement is beneficial to the academia and necessary to the future teachers. For this purpose, we base our discussions starting with the reading of the tale "A virgem santíssima do quarto de Joana" by Bernardo Élis (1915-1997). This narrative, with all its aesthetic potentiality and philosophical issues and existentialist, show us that regionalism goes beyond the idyllic or exotic and its migration to literature provides means to know a Brazil encrusted in the wilderness of the hinterlands which is read too little in the textbooks. Authors such as Ligia Chiappini (2020), Marisa Lajolo (2007), Hayden White (1994), Lloyd S Kramer (1992) and others properly referenced compose the theoretical arsenal.
\end{abstract}

Keywords: Regionalism. Historical narrative. Literary narrative. Bernardo Élis. 
A literatura do país subdesenvolvido precisa passar pelo regional, mas deve superar o simples relato naturalista.

Bernardo Élis ${ }^{1}$

\section{Breves notas introdutórias}

Gilberto de Mendonça Teles, ${ }^{2}$ ao traçar um painel da evolução do conto goiano, destaca o nome do escritor Bernardo Élis (1915-1997) por este conseguir imprimir em sua escrita testemunhos de uma época em que o Brasil pouco se conscientizava de seus inúmeros problemas sociais, mais especificamente os problemas do homem do interior. Com acentuado senso paisagista, Élis decantou possibilidades literárias dos antigos vilarejos e cidadezinhas do interior goiano e narrou não apenas os costumes e tradições locais, mas o "[...] estado miserável de desconforto físico e moral em que vivem os agregados, sujeitos a uma escravidão econômica de que muitas vezes nem sonham libertar-se", ${ }^{3}$ conforme atestamos neste trabalho através de uma leitura crítica do conto "A virgem santíssima do quarto de Joana", publicado inicialmente em 1944 na coletânea Ermos e Gerais.

David Pellauer ${ }^{4}$ considera que embora distintas, as formas essenciais da narrativa estão presentes tanto na ficção quanto na história, afinal, embora alicerçado em documentos, o historiador constrói seu texto abarcando, também, suas interpretações sobre um determinado fato. Ainda que presa a um conjunto fixo de convenções, a história se aproxima da literatura uma vez que esta

amplia a esfera social na qual se desenrola a ação ao dar atenção a pessoas comuns. Também introduz uma ênfase maior nas personagens como indivíduos nos quais devemos pensar como pessoas reais e não como meros tipos ideais ou míticos como o herói ou o vilão. Com isso vem uma ênfase crescente na complexidade social e psicológica, combinada com novas maneiras de conceber a vida interior. ${ }^{5}$

Ademais, tanto a narrativa histórica quanto a literária se aproximam por lidarem com a sensibilidade humana (matéria-comum à literatura e história), afinal a ficção nos oferece um

\footnotetext{
${ }^{1}$ ÉLIS, Bernardo. A virgem santíssima do quarto de Joana. In. Ermos e Gerais. São Paulo: Martins Fontes, 2005. p. 155-173.

2 TELES, Gilberto Mendonça. O conto brasileiro em Goiás. Goiânia: Editora da UCG, 2007.

${ }^{3}$ Ibidem., p. 66.

4 PELLAUER, David. Compreender Ricoeur. Petrópolis: Vozes, 2009.

${ }^{5}$ Ibidem, p. 107.
} 
mundo no qual nós podemos nos imaginar habitando, além de personagens que sofrem dores, angústias e alegrias e que também poderiam fazer parte do nosso mundo empírico, e para entendermos isso, "[...] temos de ir além da ficção, até o ponto em que ela se encontra com a história sob a rubrica mais ampla de discurso narrativo". ${ }^{6}$

Concernente à literatura classificada como regionalista, vemos um movimento a favor de um projeto que abarca diferentes áreas das Ciências Humanas. A refutação reside no fato de que as narrativas literárias regionais prezam pelas micro-histórias, e estas eram pouco relevantes para a abordagem histórica mais tradicional. Embora tenhamos exitosos modos de trabalho entre os estudos literários e os histórico-antropológicos, muitos ainda ignoram o discurso literário enquanto propulsor do conhecimento de outros discursos. E dentre esses exitosos trabalhos, possivelmente a interdisciplinaridade esteja avançando melhor no terreno da literatura e cultura regionais, como bem nos lembra Ligia Chiappini. ${ }^{7}$

Pretendo, portanto, traçar uma abordagem que considere tanto a história quanto a literatura saberes fomentadores de importantes questões sociais, políticas e estéticas concernentes ao regionalismo, sem que uma área se sobreponha a outra. Agindo assim, justifico a tessitura deste trabalho por acreditar que os resultados desta pesquisa podem prestar algum serviço à comunidade acadêmica, além de tentar estimular um debate que há muito se faz necessário em nosso meio.

\section{História e Literatura: possibilidades dialógicas}

Luiz Costa Lima8 pontua que "a ficcionalidade concede ao discurso que rege uma liberdade selvagem e ameaçadora a todo regime zeloso de sua verdade". ${ }^{9}$ Não nos escapa, como exemplo, o insólito presente no texto kafkaniano duelando com as leis pragmáticas - para as personagens de A metamorfose (1915), o estranho não reside no fato de Gregor Samsa transformar-se em inseto, mas sim no fato de o rapaz não mais servir como amparo financeiro à família, afinal as sociedades modernas descartam desempregados tal como artrópodes. Não nos cabe defendermos a super projeção da malha ficcional abarcando verdades institucionalizadas, entretanto, podemos pensar em um campo de possibilidades que (re)dimensione a relação dialógica entre História e Estudos Literários. Esse campo de possibilidades convoca-nos a repensar o corolário: o texto histórico encerra em si mesmo a "verdade zelosa", documentada, comprovada e datada.

\footnotetext{
6 PELLAUER, David. Compreender Ricoeur... Op. cit.,p. 108.

7 CHIAPPINI, Ligia. Regionalismo(s) e regionalidade(s) num mundo supostamente global. In: Diógenes André Vieira Maciel (Org.). Memórias da Borborema 2: internacionalização do regional. Campina Grande: Abralic, 2014. p 21-64.

8 LIMA, Luiz Costa. Documento e ficção. In. Sociedade e discurso ficcional. Rio de Janeiro: Editora Guanabara, 1986. p.187-242.
}

9 Ibidem, p. 187. 
Logramos um longo período enfrentando aguerridas discussões que pontuavam, de um lado, que somente a história poderia documentar a realidade através de um texto válido, ao passo que a literatura era inserida no espaço da fantasia e do irreal, ou seja, a verdade deveria estar separada do fabuloso através da razão. Tal embate se acentua no século XIX, quando historiadores defendem de forma mais veemente que a verdade é factual, não sendo necessário uso de técnicas específicas para confecção de uma narrativa ou uma interpelação que desvendasse o que estava escondido por trás dos fatos, uma vez que o texto histórico, por si só, seria capaz de reconstruir os eventos com exatidão científica; ao contrário do texto literário, que se preocupa somente com o imaginável ou passível de acontecer. No século que vivenciou a Revolução Industrial e todo um contexto baseado em questões sociais e políticas, era natural que se construíssem discursos históricos ceifados de interpretações dúbias ou duvidosas e que superassem as várias dicotomias instauradas na época. É nesse contexto que a história tenta se constituir como disciplina erudita, alijando-se, ainda mais, do campo literário. Entretanto, conforme postula White, ${ }^{10}$ os historiadores do período "não compreendiam que os fatos não falam por si mesmos, mas que o historiador fala por eles, fala em nome deles, e molda os fragmentos do passado num todo cuja integridade é - na sua representação - puramente discursiva".

Sob essa perspectiva, o poeta e o historiador se aproximam dos estudos aristoteleanos por produzirem tessituras narratológicas baseadas na "verdade", aceita ou não como tal pelo leitor a depender da forma como se produz o texto - o escritor deve compor suas narrativas, ainda que ficcionais, seguindo uma lógica e coerência; bem como o historiador, que ao reconstruir os acontecimentos das "histórias vividas", o faz de forma ordenada e coesa. Nos dois casos, a possibilidade se dá por meio da linguagem. E não nos esqueçamos que o texto histórico do século XIX adotou técnicas da literatura, como a oralidade e poesia: "[...] houve tantos 'estilos' de representação histórica quantos estilos literários identificáveis no século XIX". ${ }^{11}$

A virada do século XIX para o XX, entretanto, possibilita uma nova discussão em torno da relação entre história e literatura. Novas correntes teóricas abalam o estruturalismo, concepção marcante nas primeiras décadas do século $\mathrm{XX}$, ao fornecerem novo aparato explicativo aos contextos analisados pelos historiadores. Com a perda de certezas até então inabaláveis, emergem outras abordagens históricas, o que de certa forma foi bastante salutar uma vez que ao expandir seu campo de conhecimento, a história se aproxima de áreas como a linguística, antropologia, filosofia e literatura, resultando em uma instigante diversidade de estudos. Tal permitiu que diferentes pontos de vistas fossem perscrutados, e que novos campos se abrissem para o historiador, afinal a poética também pode ser útil a outros discursos. ${ }^{12}$ Com isso, a antiga dicotomia literatura versus história perde sentido. E ainda que o momento

\footnotetext{
10 WHITE, Hayden. Trópicos do discurso: ensaios sobre a crítica da cultura. São Paulo: EDUSP, 1994. p. 141

${ }^{11}$ Ibidem, p. 141.

12 VERRIER, Apud CHIAPPINI. Memórias da Borborema 2, Op. cit.
} 
sublinhasse, para o historiador, incertezas e novos desafios teóricos, estes eram vistos de forma benéfica, por exemplo, para o historiador Jacques Revel, ${ }^{13}$ que ao falar da experiência da sua geração estabelece que o fundamental é a compreensão de que, a partir da "própria prática dos historiadores do social, nasceram reflexões e exigências que determinam hoje em dia, um pouco por toda a parte, uma viragem crítica".

Graças à essa "viragem", surge uma nova forma de pesquisa histórica não exclusivamente fidedigna aos documentos e registros oficiais, porém perquirindo e resgatando memórias coletivas e individuais e considerando, com isso, diversidade de leituras e representações do passado pesquisado. As fontes oficiais, matéria-prima da pesquisa histórica, podem abarcar, nesse novo contexto, indícios, fragmentos, rastros. Também a história local, a história individual, a história que reconstrói vivências de uma pequena comunidade - afastada dos brasões e dos méritos da elite, passa a ser considerada, e aqui reside a importância do movimento: novos olhares são absorvidos pelo fazer histórico, sem que a macro-história seja solapada ou desconsiderada, porém ouvindo sujeitos históricos até então não representados e assim reconfigurando outros rumos para a relação entre história e literatura: "As relações entre história e literatura estão no centro do debate sobre a disciplina histórica na atualidade. [...]. Questionam-se os limites entre arte, ciências e filosofia, ficção e verdade; gêneros literários; narrativa histórica e narrativa literária". ${ }^{14}$

Salienta-se, outrossim, que o desenvolvimento dos Estudos Culturais possibilitou ao historiador um movimento em direção à abordagem da história pelo viés cultural, alargando, mais uma vez, os limites eruditos e tradicionais da historiografia e aproximando ainda mais os campos da história e da crítica literária, ${ }^{15}$ e aqui destaco o trabalho desenvolvido por Lloyd Kramer $^{16}$ ao pontuar a importância da crítica literária na construção de uma abordagem menos engessada da história e "ajudar a transformar a disciplina numa iniciativa mais criativa, autoconsciente e crítica". Não se trata, indubitavelmente, de uma competição entre campos epistemológicos ou sobre quem poderia relatar fatos passados, mas sim uma nova metodologia sobre como o passado pode ser considerado para a história através do objeto literário, bem como os empréstimos que o crítico literário pode tomar de forma a melhor esquadrinhar o texto ficcional, afinal "a ênfase linguística na historiografia claramente oferece novas e importantes estratégias para uma aproximação maior da história aos avanços inovadores em outras esferas

\footnotetext{
13 REVEL, Jacques (Org.). Jogos de escalas: experiência da microanálise. Rio de Janeiro: FGV, 1998, p.5.

14 FERREIRA, Antonio Celso. História e literatura: fronteiras móveis e desafios disciplinares. Revista póshistória. São Paulo: UNESP, v. 4, 1996. p. 54.

15 RIOS, Dinameire Oliveira Carneiro. Entre o histórico e o literário: um espaço de confluências. Caderno de Letras, no 26, p. 201-217, jan-jun. 2016. Disponível em: https://periodicos.ufpel.edu.br/ojs2/index.php/cadernodeletras/article/view/8544/6078. Acesso em: 24 jun. 2020.
}

16 KRAMER, Lloyd S. Literatura, crítica e imaginação histórica: O desafio literário de Hayden White e Dominick LaCapra. In: HUNT, Lynn. A nova história cultural. São Paulo: Martins Fontes, 1992. p. 137. 
do pensamento moderno". ${ }^{17}$ Sublinha-se que nesse novo contexto, os artistas passam a adotar uma nova postura ao exaltarem uma produção mais voltada aos aspectos sociais, bem como o crítico também passa a esmiuçar o objeto artístico considerando aspectos exteriores à composição: "A palavra podia continuar melódica, o verso manter seus acentos alexandrinos, sem que se deixasse de apontar para a frequência de coxos e mendigos ou de esconder o erotismo com a morte". ${ }^{18}$

Consciente de que a relação entre história e literatura já não pode mais ser lida pelos mesmos vetores de outrora, uma vez que as mudanças ocorridas suscitam outras respostas e reflexões, faço da leitura do conto "A Virgem Santíssima do quarto de Joana" essa possibilidade de aproximação entre o campo da literatura e da história. Especificamente, cotejo uma leitura de forma a compreender como o termo regionalismo, construído historicamente, migra do campo extra-literário para o interior da obra.

Foi longo o caminho até chegarmos a um cotejo de obras regionalistas que não fossem "classificadas" vilipendiosamente pelos elementos locais. Do nacionalismo romântico e sua ramificação mais proeminente, o indianismo, até a contística de Bernardo Élis, vemos que sob a guarda da concepção de regionalismo, a crítica muitas vezes pendeu para o demérito qualitativo. A própria gênese da literatura regionalista pode explicar, em parte, a postura rígida e enviesada da crítica literária, que durante muito tempo viu a literatura regionalista como "dissidência da matriz literária europeia". ${ }^{19}$ A produção de Bernardo Élis insere-se em um período em que a escrita regionalista ainda sentia os ressaibos da crítica modernista dos anos 20 , que classificava essa literatura como fruto do romantismo europeu, ultrapassada, conservadora, xenófoba e na contra-mão de um projeto nacionalista que pretendia salvaguardar e ressaltar uma escrita mais genuína, portanto contrária às pretensões de uma brasilidade homogeneizadora tão acalentada pelos modernistas e incompatível com a urbes nacional. No entanto, a crítica não se apercebia da importância do movimento. A crítica modernista atacava o regionalismo literário naquilo que era o seu próprio "calcanhar de Aquiles", ou seja, os modernistas perseguiam uma literatura nacional desamarrada das influências europeias, no entanto, rechaçavam a literatura regionalista, recebida por eles como forânea, portanto incompatível com o projeto nacionalista:

Os preconceitos com que a crítica e a história literária brasileira lidam com o regionalismo podem desvelar seus contornos ideológicos e sua dimensão política: seus protocolos de leitura literária são urbanos e ortodoxos e talvez codifiquem, no rótulo regionalismo/regionalista sua incapacidade de dar conta do modo de ser mestiço da literatura regionalista que, produto cultural crioulo como o país, é carimbado como estrangeiro aos olhos urbanos e europeizados da crítica. ${ }^{20}$

\footnotetext{
17 Ibidem., p.172.

18 LIMA, Op. cit., p. 70.

19 LAJOLO, Marisa. Regionalismo e história da literatura: quem é o vilão da história? In: FREITAS, Marco César (Org.). Historiografia brasileira em perspectiva. São Paulo: Contexto, 2007. p. 297- 328.

20 Ibidem, p. 327.
} 
Sem dúvida que certos aparatos estão mais presentes em alguns locais. Há certos elementos como linguagem, tradições, estilo de vida, comidas, vestuário, dentre outros, que se apresentam em determinados espaços (e isso ocorre tanto no espaço rural como no espaço urbano), no entanto, eles não traduzem aquele espaço. Ainda mais perniciosa torna-se a questão quando percebemos que esses elementos "regionais" são vistos como "sinônimo de localismo" no caso da literatura, como localismo literário. Considerar o regionalismo ancorado em parâmetros puramente geográficos, não somente limita um conceito por demais abrangente, como também solapa questões sociais presentes nas obras, como a essência das personagens, suas histórias de vida, angústias, temores.

Quanto à produção goiana, especificamente, coube à Hugo de Carvalho Ramos inaugurar o "ciclo da boiada e do sertão" 21 através da coletânea Tropas e boiadas, publicada inicialmente em 1917. Ramos foi muito fiel à documentação da paisagem regionalista e ao pensamento e costumes do homem rural, sem deixar de denunciar as mazelas e problemas sociais que acometiam o sertão goiano. Em 1914, Goiás inaugura sua rede ferroviária, daí que os contos de Ramos tematizam os costumes locais do sertanejo solapados pelo avanço do progresso que ceifava a pequena produção em nome dos latifúndios à serviço da pecuária. Pauta-se a escrita de Ramos na ilusão de que o progresso mudaria a vida no sertão, 22 ao passo que Élis aborda com mais pungência os problemas causados pelo ciclo do gado na cultura e vida goianas. As narrativas de Bernardo Élis trazem cenários decadentes e exauridos graças à atividade pecuarista que em nada beneficiou a população local e os pequenos produtores, que se mantinham presos às peias dos coronéis e políticos locais.

Postas essas considerações, perscruto a literatura regionalista a partir de certos aspectos típicos ou próprios de um local (e aqui podemos falar de regionalismo paulista, regionalismo carioca, regionalismo mineiro), porém que consiga ir além da simples moldura ao problematizar questões concernentes ao homem humano. Sob esse viés, busco mostrar um espaço com suas demarcações históricas, políticas, econômicas, com histórias de luta e sofrimento, e assim exaltar obras que apresentam a região rural "internalizada à ficção", ${ }^{23}$ e não como um local bucólico exterior ao texto, permitindo-nos, portanto, defender o regionalismo para o homem da cidade, do "sertão" e tantos outros. Pensar o regionalismo na literatura de forma a ressaltar o elemento humano em sua inteireza, encontra eco nas problematizações feitas em parágrafos anteriores, quando ressaltei que história e literatura podem se encontrar na micro-história - o que fica evidente no conto de Bernardo Élis lido neste trabalho.

\footnotetext{
21 TELES, Gilberto Mendonça. O conto brasileiro... Op. cit.

22 SANTANA, Rogério. Regionalismo literário no Brasil Central. In: ARAúJO, Humberto Hermenegildo de; OLIVEIRA, Irenísia Torres de (orgs.). Regionalismo, modernização e crítica social na literatura brasileira. São Paulo: Nankin, 2010. p. 205-220.

23 CHIAPPINI, Ligia. Do beco ao belo: dez teses sobre o regionalismo na literatura. Estudos históricos. Rio de Janeiro, v. 8, n. 15, p.153-159, 1995. Disponível em: http://bibliotecadigital.fgv.br/ojs/index.php/reh/article/view/1989/1128. Acesso em 18 jun. 2020. p. 158.
} 


\section{Coronelismo, padroado e alheamento em "A Virgem Santíssima do quarto de Joana"}

Ambientado em 1940 no interior de Goiás, período em que ainda se vivenciava o autoritarismo das famílias dos autointitulados coronéis, o conto "A virgem santíssima do quarto de Joana" expõe a cruel situação de mulheres que prestavam serviços nas casas das famílias de fazendeiros, sem remuneração, sem reconhecimento ou direitos trabalhistas e em troca de moradia e comida. Aqui ressaltamos a escrita de Bernardo Élis ao dar protagonismo às mulheres e ainda trazer questões psicoemocionais em uma época em que os romances e contos regionalistas centravam seus arcos narrativos na questão da luta de terras. O primeiro parágrafo do conto já nos dá mostras do quão vilipendiada fora Joana: "Joana estava agachada num canto da sala de chão úmido, com o cadáver de uma criança nos braços. Ambos sujos de sangue. A criança roxa, escangotada, em cuja boca aberta a mulher metia a pelanca dos peitos murchos". ${ }^{24}$

Em linhas iniciais, o conto traz a história de Joana, acolhida ainda criança pelo casal de fazendeiros, coronel Rufo e Dona Fausta. Prática comum nas fazendas do período, moças novas eram "doadas" por famílias humildes e miseráveis para as famílias de fazendeiros, que aparentemente "adotavam" a criança como se fosse filha, mas na verdade a menina era escravizada em afazeres domésticos, dormia em cubículos sem o mínimo bem-estar, sofria duplas e triplas jornadas sem direito a educação escolar, além de ter que servir, muitas vezes, como objeto sexual do fazendeiro e seus filhos.

Embora o conto de Élis não evidencie a vida pregressa de Joana, indícios nos mostram que ela fora para a casa da família Rufo ainda muito cedo: "O coronel Rufo criava Joana, uma menina da roça. Ela cozinhava, buscava água. Dia de domingo, calçava chinelos feitos cá e ia à missa do Rosário, das quatro horas. Depois assava bolo de arroz". ${ }^{25}$ Crescida, Joana passa a despertar atenção dos rapazes, inclusive do próprio coronel: "A pequena, entretanto, começou a desenvolver as formas de mulher de uma maneira tão bela, que punha água na boca de todo mundo. O coronel mesmo gostava de lamber com os olhos as pernas da menina, as suas formas que esmurravam as vestes $[\ldots]^{\prime \prime} .{ }^{26}$

Lembremos que as dinâmicas familiares nas fazendas e cidades do interior, nas primeiras décadas do século $\mathrm{XX}$, ainda trazem as peias da organicidade colonial. Essa dinâmica determinava que as "sinhazinhas", ou filhas dos fazendeiros abastados, deveriam se preparar para o casamento em tenra idade. Desde cedo aprendiam a bordar, costurar, manejar um instrumento musical (de preferência piano, que era sinal de status), além da aprendizagem da escrita e da leitura. Ao se casarem, teriam "à sua disposição" as "criadas de servir" - mulheres miseráveis que executariam todo o trabalho doméstico. No outro extremo social, o trabalho forçado era o destino das meninas que nasciam pobres. A partir dos 5 anos de idade, começavam

\footnotetext{
24 ÉLIS, Bernardo. A virgem santíssima... Op. cit., p. 155.

25 Ibidem, p. 156-157.

${ }^{26}$ Ibidem, p.157.
} 
a auxiliar nas lides domésticas, como manejo de animais (porcos e vacas) e no cuidado com outras crianças. Alguns anos depois, quando seus corpos apresentavam as primeiras mudanças da mocidade, essas meninas "[...] eram violentadas pelos seus senhores, patrões, gerentes, conhecidos ou estranhos, algumas delas até pelos próprios pais $[\ldots]^{\prime \prime} .{ }^{27}$

A questão sexual também tinha uma abordagem diferente de acordo com a posição econômica das moças. Meninas de famílias ricas do período, ao engravidarem de alguma paixão juvenil que não o pretendente "arranjado" pela família, ficavam escondidas por um tempo e depois o recém-nascido era depositado na "roda dos expostos", uma vez que a perda da virgindade comprometeria a possibilidade de casamento com um rapaz rico. Já para as moças de famílias pobres, a prole "[...] gerada a partir de relacionamentos considerados ilegítimos (com exceção dos incestuosos) não se constituía um problema social na época; os bastardos iriam engrossar a fileira de trabalhadores e trabalhadoras necessários para a geração de riqueza do país". ${ }^{28}$

Na narrativa de Bernardo Élis, Joana engravida de Dedé, filho do coronel Rufo. O coronel e a esposa, ao saberem do ocorrido, obrigam a moça a se casar com o coveiro da redondeza, que tinha fama de comer bebês recém-nascidos:

- Óia, sá porqueira, não carece de esconder que eu já sei de tudo. Foi o coveiro que lhe fez mal e eu vou preparar o seu casório com ele.

Atirou a um canto o fósforo apagado.

Joana empalideceu: - Não sinhô, não foi o coveiro não. Deus me livre! Depois Dedé falou que vinha casá ca gente.

Bastou aquele nome para o velho ficar medonho: - Tá pono culpa no meu filho, cachorra! Essas cadela são desse jeito. Arranjam pança e vão pôr culpa em gente de casa. Cê besta! Meu filho vai casando com a criadinha? Não se enxerga?

- Mas ele prometeu.

O coronel se lembrou de que era preciso dar força à calúnia, protestar contra a verdade com uma conviç̧ão mais inabalável do que contra a mentira. Levantouse de um soco, enfarruscou o focinho, atirou o cigarro a um canto e chegou a mão na cara da menina:

- Prometeu nada. Você tem que casar mas é com o coveiro e fique quieta, ouviu, fique quieta. Se não te mostro. Pegue a falar nisso procê ver. ${ }^{29}$

O excerto acima pontua exatamente o traço do poder dos latifundiários que marcou o período da Primeira República brasileira, principalmente o período que vai de 1894 a 1930, também conhecido como República Oligárquica - assim caracterizada por ter dado poder às elites regionais do país, dominadas pela figura do coronel. A presença do coronel Rufo nos leva a um entendimento da organização social brasileira no campo do início do século XX. Ele ratifica o autoritarismo e opressão que compunham o espaço agrícola brasileiro, incorporando, em sua pessoa, importantes instituições sociais: "Exerce, por exemplo, uma ampla jurisdição sobre seus dependentes, compondo rixas e desavenças e proferindo, às vezes, verdadeiros arbitramentos,

\footnotetext{
27 AREND, Silvia Fávero. Meninas, trabalho, escola e lazer. In: PINSKY, Carla Bassanezi; PEDRO, Joana Maria (orgs.). Nova história das mulheres no Brasil. São Paulo: Contexto, 2013. p. 68.

${ }^{28}$ AREND, Silvia Fávero. Meninas, trabalho, escola... Op. cit., p. 68.

29 ÉLIS, Bernardo. Op. cit., p.158.
} 
que os interessados respeitam". ${ }^{30}$ Desse sistema coronelista, arbitrário, desigual e perverso (o coronel ainda arvorava-se em proteger ou defender pessoas que cometiam crimes), ainda resultam características secundárias: o mandonismo, o filhotismo, a desorganização dos serviços públicos locais e o padroado.

No cenário rural do período, a religiosidade era muito presente entre a população, ainda que distante da ortodoxia de Roma. Por ser escassa a presença de padres no meio rural, era comum, ainda em nossa fase de exploração canavieira, a figura do "capelão de engenho", que atuava muito mais como servo do senhor de engenho que um discípulo de Roma, bem como se mostrava flexível quanto aos atos cruéis cometidos contra os escravos e à poligamia dos senhores de engenho. Em 1860, inicia-se um processo de "romanização" da Igreja católica brasileira com intenção de direcionar nosso catolicismo à administração mais efetiva de Roma, além de "restringir o controle de fato dos padres locais, especialmente quando ligados aos engenhos". ${ }^{31}$ Não obstante, com o fim da Monarquia e início da República, manteve-se no Brasil rural um ethos que em muito lembrava a aliança entre o monarca e a Igreja. Impingindo seu domínio e poder máximos, a figura do coronel (re)atualiza o domínio colonial no meio rural. Nesse ethos, a figura do padre funcionava como aparato ideológico de forma a manter os miseráveis em condição de resignação e silêncio, e aqui destaca-se a presença da religião no conto de Élis, utilizada pelo Coronel Rufo de forma a legitimar e "sacramentar" seu poder.

Organizadoras e agregadoras de uma experiência coletiva pautada pela fé, desde priscas eras as religiões conferiram, para muitas sociedades, sentido ao mundo e à experiência humana. Para além de um tipo particular de ação social, as religiões manejam, a partir do sagrado (símbolos, santos, rezas, altares), uma espécie de totalidade capaz de atestar a toda uma sociedade um motivo para viver. Foi durante o período medievo que se estabelece um espectro de religião distante da magia. A religião se institucionaliza e passa a ser concebida como salvação da alma, o que nas entrelinhas aponta para o apagamento das práticas religiosas tidas como pagãs aos olhos da ortodoxia cristã. Como consequência, a relação transcendental e mágica entre homem e deuses, tão naturalmente praticada por sociedades antigas, é substituída por práticas erigidas a partir da súplica e obediência a um único deus, no caso, ao Deus único da Santa Igreja Católica. Cristalizou-se, portanto, a prática religiosa católica pautada em uma espécie de "troca", em que qualquer falha moral e atos contrários à vontade de Deus levaria o indivíduo ao castigo e tormento. Não mais a re-ligação com o cosmo politeísta, essa herança medieva (e que posteriormente se dissemina aos domínios coloniais), ensina-nos a praticar os preceitos morais religiosos como um fim em si mesmo.

No Brasil, e em especial no Brasil rural, as práticas religiosas de fundo mágico amalgamaram-se ao catolicismo europeu. Isso pode explicar, em parte, a permanência de um catolicismo leigo refletido no hábito das procissões, na fé em milagres, promessas e romarias.

\footnotetext{
30 LEAL, Victor Nunes. Coronelismo, enxada e voto. O município e o regime representativo no Brasil. São Paulo: Companhia das Letras, 2012. p. 45.

31 NARBER, Gregg. Entre a cruz e a espada: violência e misticismo no Brasil rural. São Paulo: Editora Terceiro Nome, 2003. p. 29.
} 
Ademais, o caráter leigo de nossa religiosidade se deve primeiramente ao padroado, afinal "é o monarca português o chefe da Igreja no Brasil e não o papa, assumindo as funções de evangelizar, catequizar, promover o culto e manter o clero, numa espécie de cesaropapismo", 32 cabendo ao papa apenas atestar as decisões do monarca. Sob o mando do padroado impingido pela Coroa durante nossa fase imperial e posteriormente (e indiretamente) pelos coronéis rurais em nossa fase republicana, as manifestações populares misturavam-se cada vez mais ao catolicismo popular brasileiro e rural. Em Goiás, local pouco dominado pelo catolicismo tradicional, vemos que até hoje sobrevivem festas religiosas populares, como a Festa do Divino, Procissão do Fogaréu, Romaria de Muquém, ${ }^{33}$ dentre outras.

Em "A Virgem Santíssima do quarto de Joana", o narrador nos apresenta uma "virgem santíssima de folhinha, muito bondosa, docemente risonha", ${ }^{34}$ portanto, laicizada e próxima dessa manifestação religiosa de cunho popular, tão presente no Brasil rural do período. No entanto, a humanização da santa de folhinha distancia-se do popular com a inserção da preposição "até": "A virgem testemunhara tudo com aquele mesmo semblante de misericórdia e bondade. Até a noite em que a moça abriu a janela para conversar com o filho do coronel (que luar que fazia!) e ele pulou para dentro do quarto (grifos meus)". ${ }^{35}$ A partir dessa passagem, vemos uma relação entre Joana e a religiosidade marcada pela culpa e súplica, relação tal que se aproxima das práticas clericais ortodoxas, em que "tanto a obediência aos sacramentos quanto as flagelações eram instrumentos de reforma moral e dos costumes". ${ }^{36} \mathrm{~A}$ culpa que Joana carrega deve-se ao fato de manter relações sexuais com Dedé, filho de Rufo. Vítima desse sistema coronelista e patriarcal, Joana reforça o pressuposto bíblico em que a culpa sempre recai sobre as mulheres, afinal Eva já nos mostrara que a perdição da humanidade se deu por conta da insurgência feminina. Resignada e calada, à Joana não restou outra saída que não a súplica e posterior "redenção" ao casar-se com o coveiro alcoólatra.

Considerado o precursor da escola modernista em Goiás, ${ }^{37}$ Élis deixa uma produção literária firmada na situação socioeconômica do Estado ao exibir o retrato rude e cruel da sociedade sertanista, brutalizada pelo latifúndio que avançava com força e deixava famílias desassistidas, às margens, doentes e em condições subumanas. Em 1915, ano de nascimento do escritor, a "oligarquia do café" vivia seu período áureo. Em Goiás, coube aos fazendeiros a hegemonia política estadual: "Como consequência, tivemos as condições de continuidade, no século $X X$, de uma realidade semifeudal que vinha dos tempos da monarquia. Se anteriormente os 'coronéis' latifúndios tinham poder econômico, agora têm também o político (grifos do

\footnotetext{
32 SANTOS, Leila Borges Dias. Ética da Súplica: catolicismo em Goiás no final do século XIX. Goiânia: Ed. Da UCG, 2008. p. 95.

33 Idem.

34 ÉLIS, Bernardo. Op. cit., p.160.

35 Ibidem, p. 161.

36 SANTOS, Leila Borges Dias. Ética da Súplica... Op. cit., p.93.

37 TELES, Gilberto Mendonça. O conto brasileiro... Op. cit.
} 
autor)". ${ }^{38} \mathrm{E}$, claro, nessa conjuntura cabia aos coronéis "criarem" as suas leis e justiça favoráveis a si próprios e aos seus familiares, conforme notamos na fala de Dona Fausta, que ao acobertar o filho, sacrifica a vida de Joana:

- Ô, Joana, que ingratidão! - A voz dela era mais triste do que via-sacra, do que perdão de dia de Sexta-Feira Santa. - Assim que paga o trabalho que deu à gente, não é? Os tratos, as roupas, a comida... Deus me perdoa, não estou alegando. (Deu uma palmadinha em cada uma das bochechas pelanquentas, para humilharse.)

- Depois, minha filha, é pecado levantar falso desse jeito no pobre do Dedé.

[...] O coronel resmungou uma coisa qualquer. Talvez estivesse dizendo que Fausta se tinha esquecido de alegar os dezesseis anos que Joana vinha trabalhando para casa sem ganhar um só vintém, vestindo resto de roupa, calçando chinelo velho dos meninos, lavando roupa, buscando água. 39

Joana transgride uma ordem desconhecida pelo coronel, a ordem do afeto, sentimento ignorado por uma família que tem como baluarte o poder, os bens e a aparência. O diálogo acima pontua isso: Dona Fausta e Rufino sabem que o "pobre do Dedé" engravidou Joana, mas colocam na moça uma culpa que deveria ser "paga" através de um casamento arranjado com um homem temido por todos da redondeza por possuir fama de comer bebês. O conto "A virgem santíssima do quarto de Joana" reforça uma prática comum nos ermos de Goiás, e que era de conhecimento de Élis, a saber: fatos injustos tramitavam sem julgamento, como se fossem práticas normais e arraigadas.

Ainda que Bernardo Élis enfatize elementos muito próprios da região interiorana de Goiás (a começar pela paisagem, ecologia, além da linguagem característica, marcada por processos fonológicos próprios e os costumes do interior), esses são focalizados de longe, uma vez que o que interessa ao autor é a alma das personagens. Avulta-se que Élis ultrapassa as questões da terra e costumes locais ao atingir temas psicoemocionais de pessoas extremamente brutalizadas, alheadas e esquecidas nos ermos do Brasil, afinal desde muito cedo o autor "aprendeu que, de forma consciente ou inconsciente, a manifestação artística traz consigo, além do sentido do belo, de sua estética, a ideologia já dominante ou que se pretenda afirmar em determinado meio". ${ }^{40}$ A passagem em que o coronel Rufo "negocia" o casamento entre Joana e Bento, o coveiro, nos dá provas disso. Para as famílias abastadas, a virgindade das filhas era um "troféu" a ser entregue ao noivo. No caso de Joana, ao contrário, o coronel ainda paga uma quantia ao coveiro para "ficar livre do problema", em uma espécie de dote malsinado:

\footnotetext{
- Óia, seu Bento, você anda ruim de finanças, eu sei, e mandei chama você para te dá um auxílio. Vou dá uma casa, roupa, trem de cozinha - de um tudo, ouviu? O bêbado gaguejou um agradecimento babosamente alcoólico. Já desconfiava de tanta bondade. Mas o velho continuou sério. Tinha uma maneira sisuda de conversar coisas importantes de política:
}

\footnotetext{
38 ABDALA Jr, Benjamin. Bernardo Élis. Seleção de textos, notas, estudos biográfico, histórico e crítico e exercícios. São Paulo: Abril Educação, 1983. (Coleção Literatura Comentada). p. 97.

39 ÉLIS, Bernardo. Op. cit., p. 159.

40 SAUTCHUK, Jaime. O causo eu conto. Sobre Bernardo Élis e o Brasil Central. São Paulo: Geração Editorial, 2018. p. 93-94.
} 
- Mas tem isso: você vai casar com aquela morena que eu crio. Ela não é moça mais, hein!

Neste momento olhou bem firme na cara do bêbado. Ela, porém, permaneceu cretina e inexpressiva:

- Home, eu aceito. Que que tem isso agora, né mesmo, coroné?

- Então está feito...É isso mesmo, não vale nada para você isso...o casamento vai ser por esses dias, viu? ${ }^{41}$

Ainda no tocante às questões de caráter emocional, cabe ressaltar a estilística de Bernardo Élis. Predominam, em sua produção, construções frasais curtas, diretas e incisivas, acentuando ainda mais o cunho prosaico e neo-realista, bem como destacando o fio desumano. ${ }^{42}$ As imagens fortes, a cenografia regionalista imiscuída aos dramas humanos e os diálogos permeados ora pelo tom da aspereza, ora pelo tom da angústia, fortalecem ainda mais uma trama em que, ao final, o que sobressai é o desconforto físico e moral daqueles que lutam pela vida, e Joana é testemunha disso.

Após casar-se com Bento e dar à luz o filho que concebera com Dedé, Joana "[...] concebeu outro filho, agora do marido mesmo. Ela, porém, antes de o filho nascer, já tinha nojo dele, - aquele mesmo asco repugnante com que se entregara, vencida e humilhada, aos amores do coveiro". ${ }^{43}$ As sequências do conto que se apresentam após Joana engravidar, mostram um delicado embate interno, que faz com que a moça mergulhe em duras e perversas angústias, reforçando o que já fora avultado em parágrafos anteriores deste artigo: "A Literatura nos ensina a superar dicotomias: o regionalismo não precisa ser necessariamente nem exotismo, nem nostalgia, nem xenofobia. Pode ser também uma forma de conhecimento". ${ }^{44}$ A própria composição da personagem nos coloca em contato com o "outro" fora das fronteiras litorâneas, mas que possui medos e angústias universais, daí que ao extrapolarmos a classificação de uma obra "regional", acabamos por desconstruir os parâmetros normativos encabeçados por determinadas elites que não conseguem perceber que para além do homem da roça, o que temos são pessoas. O excerto abaixo nos mostra isso:

Sentia-se indignada de apresentar-se como mãe do filho de Dedé. Achava que o filho de Dedé não lhe perdoaria jamais o haver-se prostituído ao ponto de conceber um filho também do coveiro. E isso a humilhava e revoltava. Era um sentimento complicado, cheio de submissões humildes e de rebeldias impotentes. Em tais ocasiões, abraçava-se ao filho de Dedé, a quem pedia perdões e desculpas ingênuas, para satisfazer seu próprio egoísmo de mãe, enquanto se banhava num doce e terno arrebatamento de masoquismo reconfortante. ${ }^{45}$

Em "A virgem santíssima do quarto de Joana", temos um arco narrativo que intertextualiza com histórias de várias Joanas espalhadas pelo Brasil, inseridas, à revelia, em situações e contextos de ameaças, violência, talvez com o diferencial de que na narrativa de Élis

\footnotetext{
41 ÉLIS, Bernardo. Op. cit., p. 162-163.

42 TELES, Gilberto Mendonça. O conto brasileiro... Op. cit.

43 ÉLIS, Bernardo. Op. cit., p. 164-165.

44 CHIAPPINI. Memórias da Borborema 2, Op. cit. p.54

45 ÉLIS, Bernardo. Op. cit., p. 165.
} 
sobressaiam elementos muito próprios e típicos daquela região e daquele período, no entanto, as angústias que acometem Joana estão presentes em qualquer lugar, formatando então um tipo de regionalismo "[...] que ora se traduz trágico, ora cômico, ora quase fantástico; que migra do sublime presente na natureza dos ermos e gerais para a revelação do grotesco na alma subterrânea do homem que habita esses lugares". ${ }^{46}$ O grotesco, no conto, aparece mais fortemente (embora toda a história esteja no reino do grotesco e inadmissível) do ápice até os últimos parágrafos. Joana, logo após dar à luz o filho concebido com Bento, em um misto de torpor pós-parto, tenta se levantar para socorrer o filho mais velho que chorava. As descrições do ambiente em muito nos lembram os cenários medonhos e horripilantes que marcaram as produções europeias oitocentistas:

O filho de Dedé chorava. A mãe, movida pelo mesmo instinto que leva a vaca a correr para o lado do bezerro que berra, ergueu-se para acudi-lo.

Em consequência, porém, do espasmo em que caíra após o parto, não tinha clara consciência do que enxergava. A luz da candeia morria numa distância sem fim. Não alumiava, ressaltava as sombras densas, que se moviam estuporadas, como lesmas negras no fundo rubro e vacilante.

O ambiente de pesadelo fez-Ihe lembrar o que ouvira contar tanta vez: que os pagãos, nos dias de Senhora das Candeias, enxergam, no fundo impossível do limbo, uma luz muito fraca que Ihes alumia o caminho da eternidade.

"Não seria uma visão do outro mundo?"

"Seu filho não morrera pagão?"

O choro morria estrangulado pelas garras melentas da quieteza. Mas Joana podia ver melhor.

Junto à cama do filho de Dedé estava o marido, meio arcado sobre o menino. Ela pulou do jirau. ${ }^{47}$

Imiscuída ao grotesco, a ironia (marca muito presente na contística de Bernardo Élis) conduz o leitor à comicidade levantada por Mikhail Bakhtin, ${ }^{48}$ ao esquadrinhar que 0 interesse pelo grotesco, na literatura, diminui notavelmente a partir do século XIX por se relacionar ao cômico vulgar de baixa categoria ou à sátira negativa orientada contra fenômenos individuais: "Dessa maneira, toda a profundidade, todo o universalismo das imagens grotescas, desaparecem para sempre". ${ }^{49}$ Coube aos artistas do modernismo, entretanto, um resgate do grotesco imbuído da visão carnavalesca e alegre do mundo que predominou nas artes renascentistas. Essa releitura do grotesco, ainda impregnada pelo tom lúgubre do romantismo, tenta captar a força regeneradora e renovadora do riso grotesco medieval carnavalizado. ${ }^{50}$

Bernardo Élis prima por sublinhar o tom da ironia com reminiscências desse grotesco carnavalizado, porém enovelado por uma visão soturna. Leitor de Edgar Allan Poe, Élis imprimiu em sua escrita uma espécie de "humor às avessas", 51 muito mais denunciador e crítico que

\footnotetext{
46 MARCHEZAN, Luiz Gonzaga. Introdução. In: ÉLIS, Bernardo. Ermos e Gerais. São Paulo: Martins Fontes, 2005. p. XI.

47 ÉLIS, Bernardo. Op. cit., p. 167.

48 BAKHTIN, Mikhail. A cultura popular na Idade Média e no Renascimento. São Paulo: HUCITEC, 2010.

49 Ibidem, p. 39.

50 Idem.

51 TELES, Gilberto Mendonça. O conto brasileiro... Op. cit.
} 
cômico. Se ainda notamos um pouco do grotesco cômico na escrita do modernista Élis, essa despe-se da luminosidade carnavalesca renascentista ao se vestir do horror e espanto próprios do mundo contemporâneo. Tal já nos é apontado no título do conto através da evocação à figura da Virgem Santíssima, que posta na parede do quarto de Joana, mais renega a moça que a protege.

Élis ainda refina o recurso linguístico da ironia ao oferecer a "ironia trágica" ao leitor no momento em que Joana, ao se levantar da cama, depara-se com Bento mastigando algo:

Joana gritou e o coveiro desapareceu da cena. Quando ela tomou o filho nos braços, uma das coxas, marcada de dentes, estava roída, mostrando o osso. A cicatriz ria sardonicamente e Joana começou a rir também. Depois abraçou a criança, embrulhou-a bem, agachou-se no canto escuro da sala [...]. ${ }^{52}$

Na manhã seguinte à trágica ocorrência, o médico é chamado à casa de Joana. Lembremos que o conto se inicia com o recurso do flashback quando Joana aparece já com o filho morto nos braços. A narrativa, então, encerra-se com a passagem:

O doutor emperrou-a com o pé, olhou bastante a cara do menino e depois examinou-lhe as dentadas na perna.

O delegado achou que fosse cachorro que houvesse roído, mas o profissional deu a sentença:

- Essa daí morreu mesmo, aliás, morreram.

O delegado contou que ela se casara com o coveiro e quem sabe não fora ele quem comera a perna do menino? - Todos falavam que ele era louco por carne de anjinho - arrematou.

O doutor riu-se, superiormente displicente:

- Oh! Deus! Até onde irá a ignorância de nosso povo!

Então o delegado achou também que isso era mesmo pura besteira. Ninguém comeria carne de anjinho nada.

A virgem santíssima que Joana tinha no quarto, em casa do coronel, estava pregada assim na parede.

O doutor a reconheceu. Estava um pouco suja de titica de mosquito, mas bem identificável.

Olhou então para a defunta e ao invés dela viu foi uma moça novinha, com a carne iluminada de luxúria, nuinha nos seus braços.

Podia ser dez e cinco de um dia lindo, intensamente iluminado pelo sol. 53

Novamente a ironia se mostra na passagem em que o doutor reconhece Joana por causa da folhinha da Virgem Santíssima, "um pouco suja de titica de mosquito", e aqui finalizo destacando novamente a presença da religiosidade. Resta à Joana sua transcendência rumo à vida celestial através do símbolo de uma santa, único meio capaz de tirá-la de uma vida miserável e dar sentido à sua existência. Bernardo Élis, através de uma linguagem plástica e retratando um sertão muito mais cruel que idílico, conduz o leitor "[...] a ver nas criaturas seu lado invisível e essencial". ${ }^{54}$ Para nós, leitores, fica explícito o quão a invisibilidade de Joana reforça um sistema que há anos esmaga projeções de ascensão de classes menos abastadas,

\footnotetext{
52 ÉLIS, Bernardo. Op. cit., p. 168.

53 ÉLIS, Bernardo. Op. cit., p. 169.

54 VIEIRA, Emílio. O Expressionismo em Bernardo Élis e Siron Franco. Gioânia: Editora da UFG, 2005. 45.
} 
confinando às margens pessoas desassistidas e vilipendiadas em suas vontades e valores individuais, o que infelizmente perdura até hoje.

\section{Considerações finais}

Não são as respostas conclusivas que movem nossas pesquisas, e como bem pontua Umberto Eco, 55 devemos viver nossas teses como um desafio, de forma a sempre perseguirmos perguntas que não saibamos responder. Para além de uma resposta conclusiva, busquei problematizar a respeito de uma relação delicada - a relação entre o campo literário e o campo histórico, de forma que esse movimento ganhe cada vez mais fôlego e possa inspirar outros trabalhos, pesquisas, Teses e abrir novos olhares para futuros acadêmicos. Não há como entregarmos "fórmulas prontas", mas podemos e devemos caminhar em direção às práticas docentes em que o discente possa depreender que além do texto poeticamente trabalhado, há importantes questões sociais levantadas; bem como possa perceber que fatos históricos são feitos de memória, relatos pessoais, pequenas ocorrências que nos acometem diariamente, enfim, histórias individuais importam.

A história pode se imiscuir ao campo literário, sendo importante ao conhecimento dos outros discursos e implicando um maior conhecimento da própria literatura, afinal, nossas crianças e adolescentes sabem que ainda existem, infelizmente, muitas Joanas espalhadas pelo nosso país? As crianças das cidades, que muitas vezes recebem um ensino de literatura baseado no cânone litorâneo, conhecem Bernardo Élis e sua contribuição enquanto defensor de uma literatura que fale das classes menos abastadas e para elas? O próprio defendia que a literatura estava muito sofisticada e não atingia o povo. ${ }^{56} \mathrm{O}$ fato de ter nascido em uma fazenda e ter vivenciado a rotina da zona rural, permitiu ao autor levar para o papel histórias de gente humilde e miserável. Ainda que objetivas, suas histórias não ensejam relatos de observação: "A história de $O$ Tronco era verdadeira - a tragédia da cidadezinha do Duro. Fiz um romance simples, aproveitando os relatos que me contavam como uma história do folclore popular". ${ }^{57}$

Quanto ao regionalismo, pontuei neste trabalho que o tema, na literatura, é bem antigo, bem como as questões levantadas na contística de Bernardo Élis também já se fazem presentes em vários e renomados trabalhos. Tentei desconstruir discursos cristalizados, que devem ser combatidos e exibidos para o "outro citadino", e aqui reforço uma das principais reflexões dos estudos históricos: "lembrar para não esquecer". Através de uma narrativa "classificada" como literatura regionalista, vimos que não se trata de apagar o termo regionalismo, mas de combater um discurso antigo que "classifica" o rural em aspectos determinantes e que não consideram o humano em si, abarcado por questões emocionais, sociais e psicológicas, conforme nos mostra Joana.

\footnotetext{
${ }^{55}$ ECO, Humberto. Como se faz uma Tese. São Paulo: Perspectiva, 2008.

56 ÉLIS, Bernardo Apud ABDALA Jr, Benjamin., Op. cit.

57 ÉLIS, Bernardo Apud ABDALA Jr, Benjamin., Op. cit., p. 10.
} 
Bernardo Élis dá todo o protagonismo de seu conto à "criada", àquela considerada como "gentinha" na visão do coronel Rufo, e que de certa forma representa a própria visão da elite do período, desejosa em confinar o homem rural, que não condizia com a ascensão da vida moderna, naqueles ermos distantes. Restou à moça agarrar-se à Virgem Santíssima como um "suspiro derradeiro". O catolicismo de Joana (sem base institucional ou doutrinária), conforme visto neste trabalho, reforça a total devoção e entrega de pessoas humildes à religiosidade, em uma espécie de autonegação mesclada a um fervor perene no divino. Esse catolicismo popular era muito praticado nas fazendas e arraiais e era uma das principais características culturais da sociedade rural daquele período. Podemos atestá-lo no conto de Élis, na relação de entrega de Joana à santa, que deveria protegê-la de todos os males: foi a sua fé na santa que a fez ter forças para suportar o casamento com o coveiro, bem como para dar à luz um filho que ela não queria, além de "protegê-la" nos minutos finais de sua vida, afinal a vida e a morte de Joana estão entremeadas pela devoção à virgem.

As dúvidas e questionamentos internos de Joana acabam por exibir o domínio daqueles que têm poder, especificamente o poder retido nas mãos dos coronéis e que no conto é deslindado através de uma hipérbole que, ao exagerar o todo, enfatiza a desumanização, aniquilação e animalização da pessoa: "O insólito, o grotesco, apontam-nos uma deformação significativa - a degradação física e espiritual do homem - com a finalidade de representar a degradação de um tempo vivido nos ermos e gerais". ${ }^{58}$

58 MARCHEZAN, Luiz Gonzaga. Op. cit., p. XVIII 


\section{Referências}

ABDALA Jr, Benjamin. Bernardo Élis. Seleção de textos, notas, estudos biográfico, histórico e crítico e exercícios. São Paulo: Abril Educação, 1983. (Coleção Literatura Comentada).

AREND, Silvia Fávero. Meninas, trabalho, escola e lazer. In: PINSKY, Carla Bassanezi; PEDRO, Joana Maria (orgs.). Nova história das mulheres no Brasil. São Paulo: Contexto, 2013. p. 65-83.

BAKHTIN, Mikhail. A cultura popular na Idade Média e no Renascimento. São Paulo: HUCITEC, 2010.

CHIAPPINI, Ligia. Regionalismo(s) e regionalidade(s) num mundo supostamente global. In: Diógenes André Vieira Maciel (Org.). Memórias da Borborema 2: internacionalização do regional. Campina Grande: Abralic, 2014. p 21-64.

CHIAPPINI, Ligia. Do beco ao belo: dez teses sobre o regionalismo na literatura. Estudos históricos. Rio de Janeiro, v. 8, n. 15, p.153-159, 1995. Disponível em: http://bibliotecadigital.fgv.br/ojs/index.php/reh/article/view/1989/1128. Acesso em 18 jun. 2020.

ECO, Humberto. Como se faz uma Tese. São Paulo: Perspectiva, 2008.

ÉLIS, Bernardo. A virgem santíssima do quarto de Joana. In. Ermos e Gerais. São Paulo: Martins Fontes, 2005. p. 155-173.

FERREIRA, Antonio Celso. História e literatura: fronteiras móveis e desafios disciplinares. Revista pós-história. São Paulo: UNESP, v. 4, 1996.

NARBER, Gregg. Entre a cruz e a espada: violência e misticismo no Brasil rural. São Paulo: Editora Terceiro Nome, 2003.

KRAMER, Lloyd S. Literatura, crítica e imaginação histórica: O desafio literário de Hayden White e Dominick LaCapra. In: HUNT, Lynn. A nova história cultural. São Paulo: Martins Fontes, 1992. p. 131-173.

LAJOLO, Marisa. Regionalismo e história da literatura: quem é o vilão da história? In: FREITAS, Marco César (Org.). Historiografia brasileira em perspectiva. São Paulo: Contexto, 2007. p. 297328.

LEAL, Victor Nunes. Coronelismo, enxada e voto. O município e o regime representativo no Brasil. São Paulo: Companhia das Letras, 2012.

LIMA, Luiz Costa. Documento e ficção. In. Sociedade e discurso ficcional. Rio de Janeiro: Editora Guanabara, 1986. p.187-242.

MARCHEZAN, Luiz Gonzaga. Introdução. In: ÉLIS, Bernardo. Ermos e Gerais. São Paulo: Martins Fontes, 2005. p. IX-XXIX.

NARBER, Gregg. Entre a cruz e a espada: violência e misticismo no Brasil rural. São Paulo: Editora Terceiro Nome, 2003. 
PELLAUER, David. Compreender Ricoeur. Petrópolis: Vozes, 2009.

REVEL, Jacques. (Org.). Jogos de escalas: experiência da microanálise. Rio de Janeiro: FGV, 1998.

RIOS, Dinameire Oliveira Carneiro. Entre o histórico e o literário: um espaço de confluências. Caderno de Letras, no 26, p. 201-217, jan-jun. 2016. Disponível em: https://periodicos.ufpel.edu.br/ojs2/index.php/cadernodeletras/article/view/8544/6078.

Acesso em: 24 jun. 2020.

SANTANA, Rogério. Regionalismo literário no Brasil Central. In: ARAúJO, Humberto Hermenegildo de; OLIVEIRA, Irenísia Torres de (orgs.). Regionalismo, modernização e crítica social na literatura brasileira. São Paulo: Nankin, 2010. p. 205-220.

SANTOS, Leila Borges Dias. Ética da Súplica: catolicismo em Goiás no final do século XIX. Goiânia: Ed. Da UCG, 2008.

SAUTCHUK, Jaime. O causo eu conto. Sobre Bernardo Élis e o Brasil Central. São Paulo: Geração Editorial, 2018.

TELES, Gilberto Mendonça. O conto brasileiro em Goiás. Goiânia: Editora da UCG, 2007.

VIEIRA, Emílio. O Expressionismo em Bernardo Élis e Siron Franco. Gioânia: Editora da UFG, 2005.

WHITE, Hayden. Trópicos do discurso: ensaios sobre a crítica da cultura. São Paulo: EDUSP, 1994. 